\title{
Peran pola asuh orang tua terhadap pembentukan karakter pada anak
}

\author{
Siti Roini \\ Universitas Ibn Khaldun Bogor, Indonesia \\ sitiroini2501@gmail.com
}

Abstract

This study aims to determine the role of parenting parents on the child's personality carried out in several families who are housed in the bamboo bamboo Yasmin Bogor, to achieve this goal it is done by means of observation and interviews obtained from sources who work in the home / babysitter.

Keywords: parenting; child, character.

\begin{abstract}
Abstrak
Penelitian ini bertujuan untuk mengetahui peran pola asuh orang tua terhadap kepribadian anak dilakukan di beberapa keluarga yang berada diperumahan bambu raya Yasmin bogor, untuk mencapai tujuan tersebut hal itu dilakukan dengan cara observasi dan wawancara diperoleh dari sumber yang bekerja didalam rumah/babysitter.
\end{abstract}

Kata kunci : pola asuh; karakter, anak.

\section{Pendahuluan}

Faktor terpenting dalam sebuah keluarga atau sebagai orang tua adalah Anak, karena anak merupakan individu yang sedang berkembang di mana mereka sangat memerlukan perhatian khusus dari orang tuanya. Ki Hajar Dewantara (Moh. Shochib, 1998) menyatakan bahwa keluarga merupakan pusat pendidikan yang pertama dan terpenting, karena sejak timbulnya peradaban manusia sampai sekarang keluarga selalu mempengaruhi pertumbuhan budi pekerti tiap-tiap manusia. Pada lingkungan keluarga pula seorang anak menerima ajaran-ajaran dan didikan dari orangtuanya, sehingga hal tersebut secara tidak langsung akan mempengaruhi perilaku anak. Atmosfer kurang kondusif yang tercipta di lingkungan keluarga akan berakibat negatif bagi perkembangan anak. Misalnya saja, orang tua kurang aktif dalam kegiatan sosial di lingkungan sekitar rumah, sehingga anak meniru yang dilakukan orang tuanya.

Seperti halnya yang disampaikan oleh Yulia Singgih D. Gunarso (2000) mengemukakan bahwa "Pola Asuh" tidak lain merupakan metode atau cara yang dipilih pendidik dalam mendidik anak-anaknya yang meliputi bagaimana pendidik 
memperlakukan anak didiknya". Dalam keluarga fungsi pola asuh orang tua mempunyai peran dan fungsi pola asuh orangtua sebagai pembentuk kepribadian anak, membentuk karakter anak, membentuk kemandirian anak, dan membentuk akhlak anak

Keluarga merupakan salah satu faktor eksternal yang dapat mempengaruhi baik buruknya perilaku seorang anak dilingkungan keluarga maupun masyarakat. Dilingkungan keluarga inilah proses dimana terbentuknya karakter/kepribadian anak. Peran orang tua yaitu ayah dan ibu sebagai pendidik utama bagi anak. Mengenai pembentukan karakter anak, orang tua idealnya dapat memberikan waktu lebih untuk memperhatikan keluarganya. Jika orang tua dapat memberikan waktu yang berkualitas untuk keluarganya, maka orang tua dapat memberikan perhatian khusus dan memberikan contoh yang tepat untuk anaknya.

Lingkungan keluarga merupakan pendidikan yang pertama, karena dalam lingkungan keluarga inilah anak pertama kali memperoleh pendidikan dan bimbingan. Setiap anggota keluarga mempunyai peran, tugas dan tanggung jawab masing-masing, dan mereka memberi pengaruh melalui proses pembiasaan pendidikan didalam keluarga. Kehidupan anak sebagian besar waktunya lebih banyak dilingkungan keluarga dibandingkan dengan lingkungan sekolah. Masalah sulit bagi orang tua terkadang tidak bisa mengontrol diri atau bersikap yang kurang baik dihadapan anak-anaknya. Hal ini berpengaruh pada perkembangan karakter anak karena usia anak yang masih dini akan melihat dan mudah untuk mencontohkan sikap yang tidak baik, karena itu model asuhan orang tua sangat berhubungan dengan karakter anak

Pada hakikatnya sangat Pentingnya pendidikan karakter pada usia dini yang diberikan oleh orang tua yang berbasis pada kearifan lokal dapat menumbuhkembangkan anak menjadi cerdas secara intelektual, spiritual, dan emosial yang lebih insan dan berkarakter. Menurut Vigotskyl, aktivitas mental yang tinggi pada anak dapat terbentuk melalui interaksi dengan orang lain. Pembelajaran yang berkarakter akan menjadi pengalaman yang bermakna bagi anak jika ia dapat melakukan sesuatu (baik itu merubah atau mengikuti) atas lingkungannya. Karakter itu sama dengan akhlak dalam pandangan Islam dan sebagai penanda bahwa seorang itu layak atau tidak layak disebut manusia, dan pendidikan karakter itu adalah tugas semua orang.

Terwujudnya karakter bangsa yang tangguh, kompetitif, berakhlaq mulia, dan bermoral berdasarkan falsafah Pancasila yang dicirikan dengan watak dan perilaku manusia dan masyarakat Indonesia yang beragam, beriman dan bertaqwa kepada Tuhan Yang Maha Esa, berbudi luhur, bertoleran, bergotong royong, berjiwa patriotik, berkembang dinamis, dan berorientasi iptek....

Apabila produk hukum yang menjadi landasannya menggunakan istilah "akhlaq mulia" maka sewajarnya program pendidikan karakter Kemdikbud menggunakan istilah "akhlaq mulia" dan bukan "karakter" atau "karakter bangsa." Kebijakan nasional untuk memperbaiki sikap dan perilaku bangsa ini lebih baik bertajuk Kebijakan Nasional Pembangunan Akhlaq Mulia Tahun 2010-2025 yang kemudian diikuti dengan buku 
Kerangka Acuan Pendidikan Akhlaq Mulia, dst, dengan tajuk program adalah "Program Pendidikan Akhlaq Mulia. "Istilah "pendidikan karakter" atau "character building" yang digunakan dalam Inpres No. 1/2010 membuka peluang masuknya paham-paham menyimpang dalam pendidikan yang menargetkan perbaikan perilaku bangsa ini.

Pada hakekatnya, para orang tua mendambakan agar anak-anak mereka dikaruniai oleh Allah SWT putera-puteri yang relatif baik dan lengkap dari sisi fisik dan non fisik. Atas Rahmat Allah, anaknya menjadi insan yang dapat berbakti kepada Allah dan Rasulnya atau agamanya,masyarakat dan bangsanya, diri sendiri/keluarga dan lingkungan hidup sekitarnya. Tumbuh dan berkembang menjadi anak yang baik, tahu membedakan apa yang baik dan dengan yang buruk, tidak mudah terjerumus dalam perbuatan-perbuatan yang dapat merugikan dirinya sendiri maupun merugikan orang lain. Harapan ini akan terwujud apabila sejak mula orang tua menoptimalkan pengaruhnya terhadap perkembangan anak. Namun, pada prakteknya banyak orang tua yang tidak mempunyai persiapan menjadi orang tua yang sesungguhnya, malah mengikuti dan membuat cara pola asuh yang pada zaman ia masih kanak-kanak

Menurut Syaiful Bahri Djamarah (2014), pola asuh orang tua dalam keluarga berarti kebiasaan orang tua, ayah atau ibu, dalam memimpin, mengasuh, dan membimbing anak dalam keluarga secara konsisten. Orang tua perlu mengetahui informasi mengenai pola asuh yang tepat untuk anak. Dengan mengetahui pola asuh yang tepat untuk anak, orang tua dapat menerapkannya dalam mendidik anak, sehingga akan membentuk perilaku yang baik pada anak.

Sedangkan menurut Sunaryo dalam Agus Wibowo (2010) pola asuh atau parenting style adalah salah satu faktor yang secara signifikan turut membentuk karakter anak. Hal ini didasari bahwa pendidikan dalam keluarga merupakan pendidikan utama dan pertama bagi anak yang tidak bisa digantikan oleh lembaga pendidikan manapun. Saat ini hampir sebagian besar orang tua memiliki pola asuh yang unik, dimana mereka berkecenderungan agar anaknya menjadi "be special" daripada "be average or normal". Mereka merasa malu jika anaknya hanya memiliki kecerdasan yang 'pas-pasan'. Keinginan ini sejatinya tidak salah. Hanya saja mesti diingat bahwa setiap anak itu dilahirkan dengan kelebihan, kekurangan, sifat dan keunikan berbeda-beda antara satu dengan yang lain. Sehingga tidak bijak jika orang tua menginginkan semua anaknya seragam, baik karakter, sifat, maupun kecerdasannya

Gunarsa (2000) mengemukakan bahwa "Pola asuh tidak lain merupakan metode atau cara yang dipilih pendidik dalam mendidik anak-anaknya yang meliputi bagaimana pendidik memperlakukan anak didiknya." Jadi yang dimaksud pendidik adalah orang tua terutama ayah dan ibu atau wali.

Menurut Thoha (1996) menyebutkan bahwa Pola Asuh orang tua adalah merupakan suatu cara terbaik yang dapat ditempuh orang tua dalam mendidik anak sebagai perwujudan dari rasa tanggung jawab kepada anak. 
Dalam arti Pembentukan itu sendiri berasal dari kata dasar bentuk yang berarti rupa atau wujud yang ditampilkan (tampak). Pembentukan adalah proses, cara, perbuatan membentuk. Dalam hal ini pembentukan sebagai upaya membimbing dan mengarahkan (pendapat,pendidikan, watak, pikiran)

Ludwig Klages mengatakan bahwa kepribadian adalah keseluruhan dari prilaku seseorang dengan sistem. Kecenderungan yang berinteraksi atau berhubungan dengan serangkain situasi. Jadi bahwa kepribadian adalah suatu perpaduan yang utuh antara sifat, sikap, pola pikir, emosi, serta juga nilai-nilai yang mempengaruhi individu tersebut agar berbuat sesuatu yang benar sesuai dengan lingkungannnya.

Menurut Koentjaraningrat, Kepribadian adalah ciri dan watak yang diperhatikan seseorang dengan cara lahir, konsistem dan juga konsekuen pada setiap manusia yang melakukan proses sosialisasi. Proses sosialisasi ini akan berlangsung seumur hidup manusia dan kepribadian individu akan terbentuk pada tingkah laku sehingga seorang individu yang mempunyai identitas khusus akan berbeda dengan orang lain.

Penelitian ini membahas dan menelaah sikap dan perilaku orang tua yang diterapkan dalam mengasuh dan mendidik anak, karena dengan pola asuh yang tepat akan membentuk perilaku yang baik pada anak. Maka hal itu dengan berjalannya penelitian ini dilakukan hanya disebagian rumah yang berada diperumahan bambu raya taman Yasmin bogor. Dilakukan dengan cara observasi dan wawancara melalui orang yang berkerja dirumah tersebut atau biasa berprofesi sebagai baby sitter, dari hasil yang didapat pula berbeda-beda dari setiap pola asuh orang tua yang didapat oleh anak. Karena dari pekerjaan orang tuanya yang berbeda-beda ada pula orang tua yang tidak bekerja/dirumah ada pula yang berkerja tetapi melalui online sehingga bisa bekerja dirumahnya tetapi hanya menyerahkan kepada orang pekerja untuk mengasuh anakanaknya. Kemudian permasalahan yang muncul pula berbeda-beda dari pembentukan karakter/perilaku anak-anaknya.

Permasalahan yang teridentifikasi meliputi berbagai perbedaan karakter anak yang didapat dari sebagian rumah diantaranya 2 anggota lingkungan keluarganya. peran pola asuh / cara mendidik dari orang tuanya Permasalahan yang terkait dengan hal itu adalah peran pola asuh yang diberikan kepada orang tua yaitu dari peran ibu yang tidak bekerja/ibu rumah tangga, karena kurangnya kepedulian dan tidak tepatnya dalam peran pola asuh nya sehingga berdampak pada kepribadian yang timbul anak menjadi kurang perhatian, melawan apa yang diperintah orang tuanya contohnya dalam membereskan mainannya, membuang sampah pada tempatnya, membereskan tempat makannya, karena dari hal-hal seperti itu orang tunya saja tidak memberi contoh kepada anak, hanya kata-kata dan perintah yang terlontar dari ibu/ayahnya saja, Itu permasalahan yang diperoleh melalui observasi dan wawancara dari sumber yang berkaitan yaitu babysitter dari anak yang bersangkutan. Begitu juga dengan hasil identifikasi yang diperoleh dari sebagiannya lagi diantaranya 3 anggota lingkungan keluargannya yang memiliki hal sama yaitu peran ibunya yang tidak bekerja/ibu rumah tangga, dengan pola asuh yang diberikan kepada anak berbeda pula dengan dampak dari 
karakter kepribadian anak diantaranya anak memiliki kepribadian yang baik, penurut dan mandiri. Dari hasil identifikasi yang dipaparkan diatas merupakan hal yang sangat penting dalam kepedulian orang tua serta keluarganya dalam menerapkan peran pola asuh terhadap anak, karena dampak yang didapatkan akan merugikan tidak hanya untuk anak tetapi keluargannya.

\section{Metode Penelitian}

Dalam data penelitian ini diperoleh dari orang yang bekerja atau babysitter yang ikut berperan dalam masa perkembangan anak dari proses peran pola asuh orang tuanya yang dilakukan di 5 rumah dari sebagian yang ada diperumahan bambu raya yasmin dari data yang dilakukan melalui observasi dan wawancara. Dari penelitian ini bertujuan Untuk mengetahui dampak yang terjadi dalam perkembangan anak dari pola asuh yang diberikan oleh ibu/orangtua yang berkerja dirumah.

Dalam penelitian yang dilakukan menggunakan metode deskritif kulitatif yang mempunyai arti yaitu suatu prosedur penelitian yang menggunakan data deskriptif berupa kata-kata tertulis atau lisan dari orang-orang dan pelaku yang dapat diamati.

\section{A. Peran pola asuh di Bambu Raya Taman Yasmin}

Dalam menggungkapkan hasil dan pembahasan data yang diperoleh dari lapangan dengan menggunakan teknik penggumpulan data melalui observasi dan wawancara. Bahwa peran pola orang tua sangat penting yang berpengaruh untuk perkembangan dan pembentukan karater bagi anak, karena sebagai orang dewasa/ orang tua harus bisa memberikan contoh yang baik, karena pada dasarnya seorang anak mempunyai sifat yang meniru apa yang mereka lihat dan mereka dengar, maka dari itu alangkah lebih baik sebagai orang yang dewasa/orang tua dapat memberikan yang baik-baik untuk dicontoh demi perkembangan karakter anak yang baik pula.

Pada temuan masalah sosial yang berkaitan dengan peran pola asuh orang tua dalam pembentukan karakter anak yang sudah di dapatakan melalui observasi dan wawancara di sebagian perumahan yang ada di bambu raya Yasmin bogor, dalam penelitian ini hanya disebagian rumah saja yang berjumblah 5 rumah yang ada di perumahan bambu raya Yasmin dan didapat dari informasi dari pekerja/babysitter dan info dari beberapa orang tua/ibu yang ikut serta terlibat dalam perkembangan anak.

Dalam hal itu yang dimaksud dari Pola Asuh Orang Tua dalam Membangun Karakter Anak disebagian Lingkungan Masyarakat yang ada diperumahan bambu raya Yasmin itu sendiri dilihat Dari jenis pola asuh orang tuanya, pada hasil observasi dan wawancara dengan babysitter yang ikut terlibat dalam peran perkembangan anak yang bersangkutan dalam masalah sosial yang diteliti. Hal ini di lihat dari sikap orang tua terhadap anaknya dalam mengambil keputusan bersama, anak di berikan kebebasan namun tetap masih dalam pengawasan orang tua, anak di berikan kebebasan dalam mengungkapkan pendapat, perasaan dan keinginannya. Dari hal yang bersangkutan pula 
ada orang tua yang menggunakan pola asuh otoriter, dapat di lihat dari ketatnya aturan yang di berikan kepada anak. Orang tua memegang kendali penuh terhadap segala aspek kehidupan anaknya. Dalam memberikan aturan semua harus di patuhi oleh anak, dan tidak segan-segan memberikan hukuman kepada anak jika anak melanggar aturan tersebut.

Menurut Baumrind Dari hal aturan yang diberikan orang tua terdapat pengertian dari beberapa cara pola asuh yang diberikan oleh orang tua untuk anaknya, seperti dalam penjelasan dibawa ini:

1. Pola Asuh Authoritarian (Otoriter) Di dalam pola asuh ini, orang tua menentukan aturan-aturan dan batasanbatasan secara mutla pada anak. Anak tidak memiliki alternatif atau pilihan lain untuk menentukan sikapnya. Mereka harus menuruti kehendak orang tuanya. Selain itu, pada pola asuh ini Orang tua berlaku sangat ketat dan mengontrol anak dengan mengajarkan standar dan tingkah laku. Pola asuh ini mengakibatkan kurangnya hubungan yang hangat dan komunikatif dalam keluarga. Pola asuh ini memiliki ciri-ciri sebagai berikut :

a. Memperlakukan anaknya dengan tegas

b. Suka menghukum anak yang dianggap tidak sesuai dengan keinginan orang tua.

c. Kurang memiliki kasih sayang.

d. Kurang simpatik.

e. Mudah menyalahkan segala aktivitas anak terutama ketika anak ingin berlaku kreatif

2. Pola Asuh Authoritative (Demokratis) Di dalam pola asuh ini, Orang tua memiliki batasan dan harapan yang jelas terhadap tingkah laku anak, mereka berusaha untuk menyediakan paduan dengan menggunakan alasan dan aturan dengan reward dan punishment yang berhubungan dengan tingkah laku anak secara jelas. Pada pola asuh ini orang tua sangat menyadari tanggung jawab mereka sebagai figur yang otoritas, tetapi mereka juga tanggap terhadap kebutuhan dan kemampuan anak. Pola asuh ini dapat menjadikan sebuah keluarga hangat, penuh penerimaan, mau saling mendengar, peka terhadap kebutuhan anak, mendorong anak untuk berperan serta dalam mengambil keputusan di dalam keluarga. Sesuai dengan apa yang diutarakan oleh Soenarjati. dkk, dalam bukunya yang berjudul Kriminologi Dan Kenakalan Remaja menyatakan bahwa pola asuh ini memiliki ciri-ciri sebagai berikut :

a. Hak dan kewajiban antara orang tua dan anak diberikan secara seimbang.

b. Saling melengkapi satu sama lain.

c. Memiliki tingkat pengendalian tinggi dan mengharuskan anak-anaknya bertindak pada tingkat intelektual dan sosial sesuai dengan usia dan kemampuan mereka, tetapi mereka tetap memberi kehangatan, bimbingan dan komunikasi dua arah

d. Memberikan penjelasan dan alasan atas hukuman dan larangan yang diberikan oleh orang tua kepada anak. 
e. Selalu mendukung apa yang dilakukan anak tanpa membatasi segala potensi yang dimilikinya namun tetap membimbing dan mengarahkan anak-anaknya

3. Pola Asuh Permisif (Bebas) Pola asuh ini berkembang karena kesibukan orang tua sehingga waktu untuk di rumah bersama keluarga sangat minim sehingga anak dibiarkan berkembang dengan batasan-batasan mereka sendiri. Di dalam pola asuh ini, orang tua cenderung mendorong anak untuk bersikap otonomi, mendidik anak berdasarkan logika dan memberi kebebasan pada anak untuk menentukan tingkah laku dan kegiatannya. Ciri-ciri pola asuh ini adalah sebagai berikut :

a. Orang tua memberikan kebebasan kepada anak seluas mungkin

b. Anak tidak dituntut untuk belajar bertanggung jawab

c. Anak diberi hak yang sama dengan orang dewasa, dan diberi kebebasan yang seluas-luasnya untuk mengatur diri sendiri. Orang tua tidak banyak mengatur dan mengontrol, sehingga anak tidak diberi kesempatan untuk mandiri dan mengatur diri sendiri

Hal tersebut sesuai dengan yang terjadi di lapangan, mengenai jenis penerapan pola asuh kepada anak. Seperti bagaimana orang tua menerapkan pola asuh demokratis yang cenderung lebih mementingkan kebutuhan anak tanpa memaksakan kehendak terhadap anak. Mereka memberikan kebebasan kepada anak untuk memilih dan melakukan apa yang mereka anggap baik. Meskipun memberikan kebebasan namun tetap ada batasanbatasan yang di berikan kepada anak dalam mengambil keputusan. dari masalah sosial yang ada dilapangan pula ada orang tua yang bersifat tegas kepada anak dalam mempringatkan anak dalam hal kedisplinan dari hal-hal kecil seperti merapihkan mainannya, membuang sampah pada tempatnya, membereskan piring selesai makan, tetapi dal hal sekecil itu pula orang tua tidak dapat memberikan contoh secara langsung kepada anak sehingga anak tetap membantah karena mereka berfikir kenapa "saya melakukan, sedangkan orang tua saya tidak melakukannya malah menyuruh mbak yang membereskan". Dari masalah sosial yang terjadi dalam pola asuh anak itu terjadi dilapangan ketika para babysitter menceritakan secara rinci saat dilakukannya wawancara, dalam penelitian itu pulan dapat dilihat hasil yang berbeda dari setiap rumah/ sebuah keluarga dalam menerapkan peran pola asuh yang berpengaruh pada karakter anak, menjadikan anak baik/tidak itu dapat dilihat dari peran orang dewasa/orang tua yang memberikan contoh yang baik/buruk yang akan dicontoh oleh anak-anak yang melihat/mendengar.

Dalam upaya sedikit memperbaiki peran pola asuh dalam pembentukan karakter anak yang terjadi di sebagian keluarga diperumahan bambu raya taman Yasmin bogor, dipenelitian ini berupaya seperti memberikan sedikit pengertian kepada babysitter yang lebih banyak berinteraksi kepada anak-anak berjumblah 5 orang, dan ada pula pertemuan kepada 3 orang tua/ibu yang bisa meluangkan waktunya untuk ikut serta dalam penyampaian mengenai hal terkait dengan peran pola asuh kepada anak, dari hal itu pula dilakukan pada saat dilakukanya kesepakatan dari orang-orang yang 
bersangkutan agar terlaksananya penelitian ini, mengenai masalah sosial yang terjadi di perumahan bambu raya Yasmin.

\section{B. Karakter Anak}

Pada usia dini 0-6 tahun, otak berkembang sangat cepat hingga 80\%. Pada usia tersebut otak menerima dan menyerap berbagai macam informasi, tidak melihat baik dan buruk. Itulah masa - masa yang dimana perkembangan fisik, mental maupun spiritual anak akan mulai terbentuk. Karena itu banyak yang menyebut masa ini sebagai masa - masa emas anak (Golden Age ).

Sebagai orang tua dan para pendidik hendaknya memanfaatkan masa emas anak untuk meberikan pendidikan karakter yang baik bagi anak. Sehingga anak bisa meraih keberhasilan dan kesuksesan dalam kehidupannya dimasa mendatang. Namun tidak dapat disangkal, kadang orang tua atau guru tidak menyadari dampak dari sikap mereka terhadap anak justru dapat menjatuhkan mental anak. Misalnya dengan memukul dan memberikan sugesti negative kepada anak, sehingga menjadikan anak tersebut bersikap buruk, rendah diri/ minder, penakut dan tidak berani mengambil resiko yang pada akhirnya karakter - karakter tersebut akan dibawanya sampai dewasa. tentu hal ini akan menjadi penghambat baginya dalam meraih dan mewujudkan keinginannya.

Sebenarnya kesuksesan tidak hanya ditentukan oleh kecerdasan otak saja. Kesuksesan lebih dominan ditentukan oleh kecakapan membangun hubungan emosional dengan diri sendiri, orang lain dan lingkungan. Selain itu, yang tidak boleh ditinggalkan adalah hubungan spriritual dengan Allah SWT.

Adapun karakter yang dikehendaki adalah sebagai berikut :

1. Percaya diri

Kepercayaan terhadap diri sendiri sangat berpengaruh terhadap prilaku anak. Sbagai ilustrasi, seorang anak sebenarnya mampu mengerjakan soal hitungan, akan tetapi karena dia menilai soal hitungan itu sulit dan tidak dapat dikerjakan olehnya maka dia pun tidak akan bisa mengerjakannya. Oleh kerna itu membangun kepercayaan diri anak sangatlah penting. Sebagai pendidik kita dapat melakukan komunikasi dengan anak secara sehat, yaitu tidak menekan anak tetapi mengangkatnya ( menghargai segala kreatifitasnya ).

2. Memiliki rasa ingin tahu

Anak pandai bertanya tentang segala hal yang dia lihat atau dengar, akan tetapi kepandaian tersebut tidak akan terekspresikan apabila respon dari lingkungannya tidak menyenangkan. Oleh sebab itu berikanlah jawaban dengan bijaksanakepada anak yang bertanya.

3. Memiliki motivasi diri

Dalam menumbuhkan motivasi sebaiknya dilakukan sejak dini. Pemahaman anak yang diberikan sejak kecil akan dibawanya sampai dewasa. kadang orang dewasa menganggap anak kecil belum mengerti apa-apa, sehingga menyepelekan kualitas 
obrolan dengan anak. Pada kenyataannya anak akan menyerap informasi apa pun yang diterimanya.

\section{Mampu menahan diri (bersabar)}

Ketika anak menginginkan sesuatu, maka jarang sekali mereka dapat menahan keinginannya tersebut. Selalu ingin segara memiliki baik dengan cara merengek atau merebutnya langsung dari orang lain. Karakter ini dapat diubah seiring dengan pemahaman anaktentang keuntungan yang akan didapat jika dia bersabar (menunda keinginan). Misalnya, anak yang menginginkan permen diberi pilihan, jika dia mengambilnya sebelum jam istirahat maka dia mendapatkan satu tetapi jika dia mengambilnya setelah jam istirahat tiba, maka dia akan mendapatkan permen tersebut dua. Mereka akan belajar memilih tindakan dan konsekuensi dari tindakannya sendiri (jika mampu untuk bersabar, maka dia akan mendapatkan jumlah permen lebih banyak).

5. Mampu bekerja sama/bergaul

Anak memiliki kemampuan emosional dan social yang baik dalam lingkungannya. Hal ini sangat mungkin terjadi karena kondisi dalam dirinya baik dan lingkungan yang positif pun mendukungnya

\section{Peran orang tua}

Dari hal penyampaian yang terkait dengan peran pola asuh orang tua terkait dengan peran penting dari orang tua/ibu untuk

\section{Menyediakan Waktu}

Dari hasil dari hasil wawancara dan observasi yang di peroleh dari orang tua di lingkungan keluarga yang berada di perumahan bambu raya taman yasmin bogor, sangat lah penting dalam meluangkan waktu untuk anak-anak mereka sebelum atau setelah anak tiba di rumah. Sebelum anak mereka meninggalkan rumah, ada beberapa hal yang dilakukan oleh orang tua yaitu memandikan anak, menyiapkan pakaian dan makanan, menemani makan dan memberi nasehat. Begitu pula setelah anak mereka sudah tiba di rumah, orang tua juga meluangkan waktu untuk anaknya seperti menyuruh anak mereka langsung ganti pakaian, makan dan istirahat. Hal tersebut merupakan salah satu bentuk perhatian orang tua terhadap anak-anak mereka. Anak sangat senang jika orang tua meluangkan waktu untuk mereka karena anak mengartikan waktu adalah kasih sayang, karena kehadiran orang tua sangat penting bagi anak. Waktu yang di butuhkan tidak begitu lama, yang penting orang tua mampu meluangkan waktu demi anaknya di selasela kesibukannya. Karena dengan memberikan waktu kepada anak, anak akan merasakan betapa besarnya rasa kasih sayang yang diberikan oleh orang tuanya, hal ini terjadi dilapangan yang didapat dari informasi saat wawancara dimana orang tua baik itu untuk orang tua yang berkarir diluar rumah maupun berkarir dirumah ada sebagaian yang tidak bisa menyempatkan waktu untuk anak ada pula yang sempat menyempatkan waktunya sebelum beraktivitas.

2. Menghargai Anak 
Dari hasil dapat diperoleh data bahwa sebagian besar orang tua menghargai anak dengan cara memberikan kebebasan kepada anak dalam mengambil keputusan meskipun tetap dalam pendampingan orang tua. Orang tua memberi kebebasan yang di sertai dengan bimbingan kepada anak, orang tua banyak memberikan nasehat dan arahan terhadap apa yang di lakukan anaknya. Orang tua juga memberikan pertimbangan-pertimbangan mengenai apa yang telah di putuskan oleh anaknya. Selain itu orang tua juga mengikut sertakan anak mereka dalam mengambil keputusan dalam keluarga dengan tetap mempertimbangkan hal-hal yang seharusnya di ketahui oleh anak, seperti melihat umur dan kondisi anak mereka. Hal ini terjadi di lapangan disampaikan oleh orang tua yang berkarir dirumah dilihat dari hasil wawancara dan observasi dengan beberapa informan di ketahui bahwa sebagian orang tua memberikan kebebasa kepada anak mereka dalam mengambil keputusan namun tetap dalam pengawasan.

Dari pengutipan yang berkaitan dengan peran pola asuh orang tua terhadap pembentukan karakter anak sebagai berikut::

Seperti yang dipaparkan oleh Agus Wibowo (2010) bahwa pola asuh atau parenting style adalah salah satu faktor yang secara signifikan turut membentuk karakter anak. Hal ini didasari bahwa pendidikan dalam keluarga merupakan pendidikan utama dan pertama bagi anak yang tidak bisa digantikan oleh lembaga pendidikan manapun. Saat ini hampir sebagian besar orang tua memiliki pola asuh yang unik, dimana mereka berkecenderungan agar anaknya menjadi "be special" daripada "be average or normal".

\section{Kesimpulan}

Pembentukan karakter pada diri anak tidak hanya terbentuk dengan sendirinya baik dan buruknya karakter anak merupakan pengaruh besar yang harus diperhatikan oleh orang tua atau orang dewasa, karena pada dasarnya perkembangan anak merupakan hal yang perlu hati- hati dalam penerapanya. Sebagai orang tua terutama seorang ibu harus berperan besar dalam tumbuh kembang anak, seorang ibu merupakan guru pertama yang dapat memberi pengaruh sangat besar untuk anak-anaknya, karena hal apa saja yang seorang ibu lakukan akan ditiru dan didengar oleh anak. Padadasarnya sifat anak adalah meniru jadi sebagai ibu /orang dewasa memang harus berhati-hati dalam melakukan sesuatu dihadapan anak, apabila seorang ibu melakukan hal baik/memberi contoh yang baik maka akan berpengaruh baik pula terhadap perkembangan anak begitu pula sebaliknya. Seperti yang tercantum pula pada terjemahan salah satu surat didalam al-quraan seperti "wahai anakku, dirikanlah shalat dan suruhlah (manusia) mengerjakan yang baik dan cegahlah (mereka) dari perbuatan yang mungkar dan bersabarlah terhadap apa yang menimpa kamu. Sesungguhnya yang demikian itu termasuk hal-hal yang diwajibkan (oleh allah). Dan janganlah kamu memalingkan mukamu dari manusia (karena sombong) dan janganlah kamu berjalan di muka bumi dengan angkuh. Sesungguhnya allah tidak menyukai orang-orang yang sombong lagi membanggakan diri (q.s. Luqman ayat 17-18)" 
Dalam pembentukan karakter seorang terhadap anak melalui komunikasi sangat berpengaruh, orang tua harus membentuk sebuah komunikasi yang baik antara orang tua dan anak. Pada dasarnya anak akan meniru, mendengarkan dan berempati dengan ada yang ada disekitarnya.

Karena pada hakikatnya sebagai orang tua/ibu bisa memberikan hal yang terbaik untuk keberhasilan tumbuh kembang anak, sayang sekali apabila tumbuh kembang anak tidak diperhatikan/acuh tak acuh sebagai orang tua/keluarga, yang hanya bisa menyerahkan anak-anaknya kepada babysitter/pengasuh anak yang pada dasarnya mereka hanya membantu apa yang diperlukan anak, dan apabila anak tidak ditanggani oleh babysitter yang tepat akan berdampak tidak baik pila pada karakter anak itu sendiri, tatapi apabila kepada orang yang tepat pula tidak akan baik bagi karena akan berdampak pada psikologi anak yang menjadikan anak lebih dekat kepada babysitter dari pada orang tuanya sendiri, kenapa bisa seperti itu pada dasarnya anak memerlukan sosok seseorang yang perhatian dan yang bisa memberikan waktu kepada dirinya.

Didalam permasalahan sosial yang terjadi dilapangan diatas merupakan salah satu contoh bahwa peran asuh orang tua sangat-sangat harus diperhatikan dan lebih berhatihati dalam penerapannya bagi anak, walaupun orang tua/ibu yang bekerja diluar rumah atau berkarir dirumah sangat penting dalam meluangkan waktunya untuk anak-anak mereka walaupun hanya sebentar setidaknya memberikan hal-hal yang baik pada anak, seperti meluangkan waktu dan perhatiannya. Dalam hal ini pula saat penelitan dilaksanakan bukan untuk menggurui kepada setiap orang tua tetapi hanya sedikit memberi pengertian bahwa peran seorang tua/orang dewasa itu harus memberi contoh yang baik dan peran pola asuh pula sangat harus diperhatikan demi kelangsungan hidup anak yang mempunyai karakter yang baik, karena hal itu tidak hanya berdampak baik pula bagi lingkungan keluarga tetapi berdampak pula untuk lingkungan masyarakat dan teman-teman nya kelak. Maka sebagai orang dewasa yang tau begitu besar peran pola asuh asuh terhadap perkembangan anak, maka lebih diperhatikan dan lebih dikhususkan dipenerapan dalam sehari-hari setiap, setiap langkah, dan waktu harus diperhatikan untuk anak yang sedang tumbuh kembang.

\section{Daftar Pustaka}

Abbas, H. 2008. Hadits Tentang Pendidikan Karakter atau Akhlak. https://media.neliti.com/media/publications/264720-pendidikan-karakterprespektif-al-quran-4e0376cd.pdf

Abdullah Yatimin. 2002. Studi Akhlak Dalam Prespektif Al-Quran. Jakarta: Amzah.

Ahsin Sakho Muhammad. 2010 et.,all., Al-Qur'an dan Tafsirnya, Jakarta: Lentera Abadi. Pawitasari, Erma, Mujahidin, Endin, AND Fattah, Nanang. "Pendidikan Karakter Bangsa dalam Perspektif Islam (Studi Kritis Terhadap Konsep Pendidikan Karakter Kementerian Pendidikan \& Kebudayaan)" Ta'dibuna: Jurnal Pendidikan Islam [Online], Volume 4 Number 1 (6 April 2015)

Fathurrohman, P. Dkk. 2017. Pengembangan Pendidikan Karakter. Bandung: PT Refika Aditama.

Hyoscyamina Darosy, E. 2011. Peran Keluarga dalam Membangun Karakter Anak. Jurnal 
Psikologi Undip

Winarno Surakhmad, Pendidikan Nasional Strategi dan Tragedi, Jakarta: Kompas Penerbit Buku, 2009

Zubaedi, Desain Pendidikan Karakter, Jakarta: Kencana Prenada Media Group, 2011 